\title{
The Realization Path of Teaching Management Process Reengineering in the Chinese Universities
}

\author{
Zhe Wang ${ }^{*}$, Jiahuan Liu \\ School of Marxism, Central University of Finance and Economics, Beijing, China \\ Email address: \\ wangzhewudi62@163.com (Zhe Wang), liujiahuanyou@163.com (Jiahuan Liu) \\ ${ }^{*}$ Corresponding author
}

To cite this article:

Zhe Wang, Jiahuan Liu. The Realization Path of Teaching Management Process Reengineering in the Chinese Universities. Teacher Education and Curriculum Studies. Vol. 6, No. 1, 2021, pp. 12-17. doi: 10.11648/j.tecs.20210601.13

Received: January 22, 2021; Accepted: January 29, 2021; Published: February 2, 2021

\begin{abstract}
With the popularization of higher education in China, the difficulty of teaching management and personnel training in Colleges and universities has increased significantly. The traditional management concept and administrative management mode can not meet the needs of social development. How to make full use of the existing resources, effectively improve the management efficiency, reduce the cost of education, and improve the quality of teaching has become an urgent problem. Business process reengineering (BPR) is a kind of management philosophy and related activities in order to improve the efficiency of enterprise operation and reduce the cost. This study introduces the theory of business process reengineering into the field of higher education management in China. Based on the BPR theory and the experience of western colleges and universities of business process reengineering, this article explores the connotation of the process reengineering of teaching management in Chinese universities and the current problems of teaching management in Chinese universities, and then discusses the realization path of business process reengineering of university teaching management in combination with the steps of enterprise process reengineering, and the key elements for its success. It provides some constructive ideas for deepening the reform of teaching management in Chinese universities and promoting the improvement of teaching management.
\end{abstract}

Keywords: Business Process Reengineering, Teaching Management, Chinese Universities

\section{Introduction}

In recent years, China's higher education has entered a stage of popularization and popularization, followed by the increasing difficulty of teaching management and personnel training. At present, the teaching management mode of Chinese universities mostly follows the management mode of government agencies. The administrative management mode is characterized by outdated management concept, redundant organization, rigid management function and fuzzy management process, which seriously affects the improvement of teaching quality in Colleges and universities. With the limitation of the traditional mode, how to make full use of the existing human, material and financial resources to improve the quality of education and reduce the cost of education is an urgent problem to be solved.

Business Process Reengineering (BPR) is a new management idea proposed by Michael. Hammer and James. Champy, which aims to improve the operating efficiency of enterprises and reduce their operating costs. Introducing BPR theory into the field of university teaching management, reorganizing work responsibilities around training goals, breaking rigid management models, reshaping work processes, and realizing the transformation from a function-centric management method to a process-centric management method, thereby universities' teaching management procedures are simplified, working hours are shortened, work costs are reduced, and work quality and efficiency are improved. It provide valuable services to teachers and students in the best, fastest, most economical and most convenient way, so as to effectively enhance the efficiency and competitiveness of universities. Therefore, based on the theory of process reengineering and the experience of western colleges and universities, this article explores the realization path of process reengineering of teaching management in Chinese universities, which has practical guiding significance for deepening the reform of teaching management in universities. 


\section{The Connotation of Teaching Management Process Reengineering in Universities}

\subsection{Business Process Reengineering}

The theory of business process reengineering was born in the 1990s to achieve the purpose of reducing costs, improving quality, strengthening services, and improving work efficiency The original business process of the enterprise was re-studied and completely transformed [11]. Davenport puts forward the concept of business process redesign in The New Industrial Engineering: Information Technology and Business Process Redesign. He thinks that BPR is the analysis and design of workflow and procedure in and among organizations [6]. Alter thinks that BPR is a kind of methodological procedure that uses information technology to fundamentally change the enterprise process to achieve the main enterprise goals [3]. Venkatraman believes that BPR is a business restructuring centered on the use of information technology [16]. The core idea of BPR is as follows:

First, business process oriented. Business process reengineering breaks the traditional mode of dividing the work according to the function and then dividing the work according to the process. It reconstructs the operation mechanism and organizational structure of the enterprise with the process as the core, and transforms the vertical function control in the traditional organization into the horizontal coordination of various activities in the process, So as to minimize the overlapping of work functions and cumbersome cross departmental communication, and realize the effective management and control of the process.

Second, take the customer demand as the starting point. It is necessary to redesign the new process or modify the original process from the perspective of customers, establish a business process system oriented to customers and markets and a flat process organization structure, and realize the transformation from traditional functional management to process management, so as to shorten the information transmission channel and time, and improve the response speed of enterprises to customers and markets.

Third, take information technology as an effective tool. Relying on advanced information technology, business process reengineering breaks through time and space constraints and promotes the rapid transmission of information flow within the organization, thus promoting the speed and efficiency of business process reengineering.

\subsection{Teaching Management Process Reengineering in Universities}

With the continuous development and improvement of BPR theory, relevant scholars have introduced it into the field of higher education. Penrod and dolence [14] believe that with the rising cost of higher education and the development of information technology, higher education needs to carry out "process reengineering" to adapt to the change. In the process reengineering of universities, we need to establish a learning organization, have strong leadership to promote change, introduce a new organizational culture that emphasizes responsibility, responsiveness and service, pay attention to improving the work process, use total quality management (TQM), and establish a flat and flexible organizational structure. Grotevant, S. M [10] believes that the application of BPR in higher education mainly includes seven aspects: strategic development planning, scientific research and scientific research management, human resource management, financial management, infrastructure management, student service and supplier management. Caldwell [4] linked the view of business process reengineering with the field of education, and proposed that the vitality of advanced technology in the field of education will prompt schools to abandon the traditional education model, choose student-centered organizational structure design, and reengineering the existing management process. Ahmad, H., Francis, A., and zairi, M. put forward seven key factors for the success of process reengineering in Colleges and universities : teamwork and quality culture, quality management system and satisfactory rewards, effective change management, less bureaucratic and participative, information technology/information system, effective project management and adequate financial resources [2]. The process reengineering of MIT is a very successful case in the field of higher education [18]. MIT defines process reengineering as a fundamental rethinking and thorough redesign of the school's support process to achieve significant performance improvement. In the face of complicated management processes and ever-increasing administrative expenditure budgets, MIT has focused its process reengineering on the management process, analyzes and improves six core processes: document management, supplier management, postal service management, equipment management, information management, and human resource management. After more than 5 years of process reengineering, finally achieved the goal of saving US\$40 million in management costs each year, and further promoted the improvement of the quality of MIT education.

The teaching management of colleges and universities is to organize the teaching resources such as human resources, material resources and information in the teaching process according to the talent training goals, certain management principles, procedures and methods, establish a normal and relatively stable teaching order, make the teaching process achieve coordination, high efficiency and optimization, ensure the completion of teaching tasks, and cultivate all-round talents. The teaching management process reengineering of universities focuses on the various business processes of the whole process of teaching management, takes the talent training goal as the foothold, and serves the needs of teachers and students as the starting point. Through combing the teaching process and work responsibilities, discovering the defects or shortcomings of the existing teaching management process, re-adjusting, choosing and optimizing each process link of the business process, breaking the original functional 
division of labor mode and organizational structure and carrying out a fundamental business process transformation, finally realize the integration and optimization of resources, reduce the cost of school teaching management, enhance core competitiveness, promote the significant improvement of key performance indicators such as speed, quality, cost, and service in the teaching management of universities, and creative transformation and innovative development of the internal management of universities.

\section{Problems Existing in the Teaching Management of Chinese Universities}

\subsection{Management Concept Is Backward, Teachers and Students' Needs Are Not Taken Seriously}

In line with the planned economy and macro-management system, the positioning of the teaching management functions of Chinese universities is mostly centered on "control", implementing one-way, passive management from top to bottom from managers to managed. The focus of this kind of teaching management is to ensure the normal, orderly and controllable teaching order, pay attention to the inspection and control of teaching and other management functions, emphasize how teachers and students accept the management, but rarely consider the needs of teachers and students and how to meet their needs and provide corresponding services to ensure the realization of teaching goals. This management concept has been unable to adapt to the era of popularization and popularization of education and the two-way flow of talents. Higher education is a kind of service, and its service targets are students and teachers. Only by providing high-quality teaching resources and services and improving teaching quality, can colleges and universities attract excellent students; only by providing high-quality teaching platform and resources, simplifying teaching management process and improving management efficiency, can they absorb and maintain high-quality teacher resources. The various work processes of colleges and universities should establish the concept of people-oriented and centered on the needs of teachers and students in order to better design and optimize the process.

\subsection{There are Many Management Levels and the Process Is Not Running Smoothly}

Most of the teaching management modes in Chinese universities adopt the functional management mode, which decomposes the tasks and functions of teaching management into different levels such as schools and colleges vertically and different functional departments horizontally, forming a pyramid type multi-level organizational structure from top to bottom. The operation of the entire structure is a command transmission and execution system, similar to the government's administrative control system. The functional teaching management organization established in accordance with the principle of division of labor can clearly define the responsibilities of each department, but the excessively detailed division of labor can improve efficiency while splitting the complete process across the internal departments of the organization into several parts, which is easy to produce "Separate governance" phenomenon; it is difficult to manage the blanks or overlapping areas in the process. The blank areas in the process cause process breakpoints, and the overlapping areas in the process may cause repeated management, thereby causing management confusion.

At the same time, due to the continuous business process is divided into a variety of simple, specialized tasks, resulting in increased work links, need multi department cooperation. Due to the bloated organizational structure of the process, the multi-level task communication, and the lack of effective information exchange and communication between departments, the task execution is delayed.

In addition, the functional management mode pays attention to various approval procedures and control procedures, so that each process needs to be approved from teachers and students to the teaching management secretary, the dean of teaching, the departments of the academic affairs office, the leaders of the academic affairs office, and so on. There are too many approval and coordination links in the process, and the procedures are cumbersome, resulting in the rigid administrative color in the process of teaching management in Colleges and universities.

\subsection{Management Information Is Fragmentary and Information Resources Cannot Be Shared}

Due to the division of work flow by functional management, all kinds of information of teaching management mostly exists in various colleges and functional departments, forming "information islands" one by one, without establishing an advanced information platform to realize the sharing of teaching information resources. After each teaching task is assigned, teaching management departments need to invest a lot of time and energy to re collect and summarize information, resulting in low efficiency. Only by applying network technology, ERP and other management software to integrate various processes in the organization and establish a process oriented operation mode, can universities better realize cross department and cross business information sharing and processing.

\section{The Realization Path of Teaching Management Process Reengineering in Chinese Universities}

The teaching management process reengineering in Chinese universities should base on the theory of business process reengineering, combines with the university's own characteristics, actual conditions and talent training goals, and carries out process reengineering in a targeted manner. In the process of implementation, there are generally five steps: 


\subsection{Define the Goal of Reengineering}

The first step of teaching management process reengineering in universities requires the leadership of universities to design and position the orientation, vision, mission and process reengineering objectives of universities from a strategic height, which is the starting point and ultimate goal of process reengineering. After clarifying the reengineering goals and strategic positioning, universities need to decompose it into the core process goals of the department and a specific work flow goal around this goal, so that the teaching management department can understand whether the existing processes really support the university strategy service, and ensure the realization of the school's overall strategic goals through the implementation of the various processes and goals of the department. School leaders should fully understand the necessity and connotation of teaching process reengineering in universities, and as the main person in charge and promoter of process reengineering, give positive support to the work of reengineering.

\subsection{Business Process Description}

Business process description (BPD) is to transform the functional organization structure into a process organization structure, and to express its content in a structured language to draw a comprehensive flow chart. In this process, colleges and universities need to describe and analyze the job content and job responsibilities of various departments and positions, clarify the specific responsibilities and work process of each teaching management department, confirm the specific structure and operation mode of the process, find out the main business activities of colleges and universities on this basis, and construct the comprehensive flow chart of colleges and universities.

\subsection{Business Process Analysis}

The purpose of business process analysis (BPA) is to find out opportunities for improvement through scientific and effective evaluation of existing processes, that is, to determine which processes to choose and which key businesses in the process need to be reengineered. The teaching management of colleges and universities involves many links, not all processes are inefficient and need to be reformed. Therefore, it is very important for colleges and universities to identify the core process.

\subsection{Business Process Design}

Business process design is the design phase of the new process around the core process on the basis of process description and analysis. The teaching management of Chinese universities generally involves many responsible individuals such as schools, academic affairs offices, colleges, directors of teaching and research sections, academic secretaries, teachers, and students. Most of the management content includes the school's development of talent training programs and various teaching documents, the teaching plan issued by the teaching office every semester, the organization of teaching topics, the maintenance of teaching order, and teaching inspections. The academic secretary implements the teaching plan, curriculum arrangements, and teaching inspections, As well as the teacher's classroom teaching, final grade assessment and other links, it can be said that there are many people involved and the process is complicated. Colleges and universities should sort out and design each link of the core process of teaching management, the degree of service and the business relationship between the two parties being served, eliminate non-value-added management processes, adjust core value-added processes, streamline redundant levels and tedious and repetitive management activities, and rebuild new work process. At the same time, colleges and universities should adjust the organizational structure, human resources, equipment and facilities, rules and regulations, job responsibilities, information technology platform designed for the new process, so as to establish the organization and operation mechanism suitable for the process reengineering, realize the interlocking of teaching management process, assign responsibilities to people, accurately connect teachers and students, and promote the improvement of teaching

\subsection{Business Process Implementation and Feedback}

Because of the great risk and uncertainty of BPR, colleges and universities can choose specific process to pilot according to the optimized business process model. The experience and lessons accumulated in the pilot project can be used in other BPR projects. After the pilot project has achieved certain results and the operation is relatively stable, colleges and universities should make plans on how to make the other parts of the organization reengineer smoothly, and implement the switching of various business process reengineering projects of teaching management in colleges and universities according to the order of the plan with full consideration of risks and benefits. In this process, the internal information system of university management department should cooperate with the work process after transformation. Process reengineering is a dynamic process. When the new process system is implemented, it is necessary to monitor and evaluate the new process, and timely obtain the feedback from the departments, teachers and students involved in the process, so as to find out the existing problems and further improve it.

\section{Key Factors of Teaching Management Process Reengineering in Chinese Universities}

\subsection{Focus on Top-level Design}

The process reengineering of teaching management in Chinese universities is inseparable from the top-level design and high attention of school leaders. Only when university leaders fully realize that the current university education and teaching management can not meet the needs of the 
development of the times, realize the importance of teaching management process optimization and reengineering, carefully design and demonstrate the mission, vision and talent training objectives of the university, establish the objectives of teaching management process reengineering, and effectively promote it, can they provide corresponding system and resource guarantee for the reform and eliminate the negative factors that hinder process reengineering, mobilize the strength of teachers and students in the school to unite and cooperate, and ultimately promote process reengineering to give effect.

\subsection{Strengthen the Construction of Management Team}

Teaching administrators are both participants and executors of the reengineering of teaching processes in universities. The teaching management process reengineering in colleges and universities is inseparable from the teaching administrators' experience and reform suggestions for various teaching tasks. Therefore, colleges and universities should pay full attention to the construction of teaching management team, regularly organize courses on process reengineering, train teaching management personnel in knowledge structure, working ability and professional quality, promote their in-depth understanding of the concept and method of teaching process reengineering, be familiar with the specific work of process and network information platform, and strengthen their organizational learning and innovation abilities so as to provide better human resource guarantee for BPR.

\subsection{Establish the Supervision and Feedback Mechanism}

Firstly, we should establish a supervision and management mechanism among teachers, students and teaching management departments, change "management" into "service", fully mobilize the enthusiasm and participation of school teachers and students, provide more decision-making, suggestions and supervision power for teachers and students, give full play to the feedback and evaluation role of teachers and students on teaching effect, so as to obtain timely feedback in teaching management process. Through communication, we can get more valuable suggestions from teachers and students, so as to further optimize the process and promote the smooth operation of teaching management.

Secondly, we must pay attention to the performance appraisal and feedback of the teaching administrators in the teaching management process. Whether the reengineering process can run smoothly is inseparable from the coordination of teaching administrators at various management levels. Therefore, colleges and universities should attach great importance to the work performance appraisal and feedback of teaching administrators. On the one hand, colleges and universities should focus on the reengineering goals of the teaching management process and the requirements of various work processes, determine the key performance indicators to achieve the goals of the process, establish a teaching management performance evaluation mechanism that combines the characteristics of the school, and implement the entire process of evaluation of the teaching management process to promote standardization and institutionalization of the work process of university management. On the other hand, it is necessary to give full play to the role of the teaching supervision group and the teaching steering committee, follow up and supervise the problems existing in the performance appraisal, and promote the timely improvement of related problems. At the same time, it is necessary to continuously improve the performance appraisal system, refine performance management indicators, and revise unreasonable standards in a timely manner, so that performance appraisal can not only mobilize the enthusiasm and initiative of teaching administrators, but also highlight the effect of teaching management assessment, stimulate the continuous innovation of relevant responsible individuals of teaching management, and promote the effect of performance improvement.

\subsection{Improve the Level of Informatization}

The network information platform is an effective tool and technical support to ensure the reengineering of the educational management process of colleges and universities. Colleges and universities should innovate the existing teaching management process, redesign the network information platform around each link of the reengineering process, take service as the guidance, take simplification and efficiency as the principle, use advanced network information technology to promote the sharing of teaching information and resources in colleges and universities with advanced network information technology, realize paperless office, and promote the standardization, informatization and efficiency of teaching management process in colleges and universities.

\section{Conclusion}

First class teaching management is an important guarantee for building a world-class university. With the progress of the popularization of higher education in China and the construction of double first-class, it is urgent to introduce advanced management concepts and management models. Therefore, this research introduces the BPR theory of corporate management into the teaching management of Chinese universities. By analyzing the current situation of teaching management in colleges and universities, combined with BPR theory, the realization path of teaching management process reengineering in Chinese colleges and universities is constructed from five steps: define the goal of reengineering, business process description, business process analysis, business process design, business process implementation and feedback. The key elements in the implementation process are also be proposed. This study provides useful ideas for changing the concept of teaching management, simplifying the management process and improving the management efficiency in China's colleges and universities. Teaching management process reengineering in the Chinese Universities is a very complex project, this study only proposed the basic construction steps and thinking. In the 
future, more detailed researches should be combined with the specific characteristics of Chinese universities and teaching management process, expand research samples, empirical research and analysis, so that the research results can be further verified and improved in the teaching management practice.

\section{References}

[1] Adenso-Díaz, B., and Canteli, A. F (2001). Business process reengineering and university organisation: A normative approach from the Spanish case. Journal of Higher Education Policy and Management, 23 (1): 63-73.

[2] Ahmad, H., Francis, A., and Zairi, M. (2007). Business process reengineering: critical success factors in higher education. Business Process Management Journal, 13 (3): 451-469.

[3] Alter, A. (1990). The corporate make-over. CIO, 4 (3): 32-42.

[4] Caldwell, B. (1998). Strategic leadership, resource management and effective school reform. Journal of Educational Administration, 36 (5), 445-461.

[5] Davis, J., and Mehta, K. T. (1997). Reengineering a school of business of the future: a mission/vision model for higher education in transformational times. Sam Advanced Management Journal, 62 (2): 8-15.

[6] Davenport, T. H. and Short, J. E. (1990). The new industrial engineering: information technology and business process redesign. Mit Sloan Management Review, 31 (4).

[7] Dougherty, J. D. (1994). Business Process Redesign for Higher Education. National Association of College and University Business Officers, One Dupont Circle, Washington, DC 20036.

[8] Fasna, M. F. F., and Gunatilake, S (2019). A process for successfully implementing BPR projects. International Journal of Productivity and Performance Management, 68 (1): 1102-1119.
[9] Gerstner, L. V. J (1995). Reinventing Education: Entrepreneurship in America's Public Schools, and the Special Role of Business in Catalyzing Educational Change. Multimedia Today, 3 (5): 24-29.

[10] Grotevant, S. M. (1998). Business engineering and process redesign in higher education: Art or science. URL: http://www.educause.edu/copyright.html, CAUSE, 98.

[11] Hammer, M., and Champy, J (1993). Reengineering the corporation: A manifesto for business revolution, 36 (5): 0-91.

[12] Lundquist, R. (1998). Quality improvements of teaching and learning in higher education: a comparison with developments in industrial settings. Teaching in Higher Education, 3 (1): $51-62$.

[13] Mavetera, C. G., Huisman, M., and Mavetera, N. (2012). The effect of BPR on organizational strategy and the role of SDMS: a case of South Africa's merged higher education institutions. Environmental Impact Assessment Review, 45 (2): 38-45.

[14] Penrod, J. I., and Dolence, M. G. (1992). Reengineering: A Process for Transforming Higher Education. Professional Paper Series, 9: 1-44.

[15] Sibhato, H., and Singh, A. P. (2012). Evaluation on BPR implementation in ethiopian higher education institutions. Global Journal of Management \& Business Research, 12 (11): $1-28$.

[16] Venkatraman, N. (1994). IT-enabled business transformation: from automation to business scope redefinition. Sloan management review, 35: 73-73.

[17] Vladimirovna, B. A., Korostelev, A. A., Shepelyuk, O. L., Rodionova, A. E., Fardeeva, I. N., and Maseleno, A. (2019). Reengineering of Business Processes of the Higher School: Its Prerequisites. International Journal of Recent Technology and Engineering (IJRTE), 7 (6S5): 101-104.

[18] Wang Xiaozhou, Hong Xiaojun, and Zhou Guojun (2006). Application and Enlightenment of business process reengineering in American Higher Education. Higher agricultural education, (10): 89-92. 